\title{
The Ethical Value of The Youth at Arfiah Shelter Home
}

Mohd Izhar Ariff Mohd Kashim, Norhafizah Musa, Nurul llyana Muhd Adnan, Siti Suhaila Ihwani, Adibah Muhtar and Azahar Yaakub

To Link this Article: http://dx.doi.org/10.6007/IJARBSS/v12-i1/12264

DOI:10.6007/IJARBSS/v12-i1/12264

Received: 13 November 2021, Revised: 17 December 2021, Accepted: 09 January 2022

Published Online: 23 January 2022

In-Text Citation: (Kashim et al., 2022)

To Cite this Article: Kashim, M. I. A. M., Musa, N., Adnan, N. I. M., Ihwani, S. S., Muhtar, A., \& Yaakub, A. (2022). The Ethical Value of The Youth at Arfiah Shelter Home. International Journal of Academic Research in Business and Social Sciences, 12(1), 1999-2007.

\section{Copyright: (c) 2022 The Author(s)}

Published by Human Resource Management Academic Research Society (www.hrmars.com)

This article is published under the Creative Commons Attribution (CC BY 4.0) license. Anyone may reproduce, distribute, translate and create derivative works of this article (for both commercial and non0-commercial purposes), subject to full attribution to the original publication and authors. The full terms of this license may be seen at: http://creativecommons.org/licences/by/4.0/legalcode

Vol. 12, No. 1, 2022, Pg. 1999- 2007

Full Terms \& Conditions of access and use can be found at http://hrmars.com/index.php/pages/detail/publication-ethics 


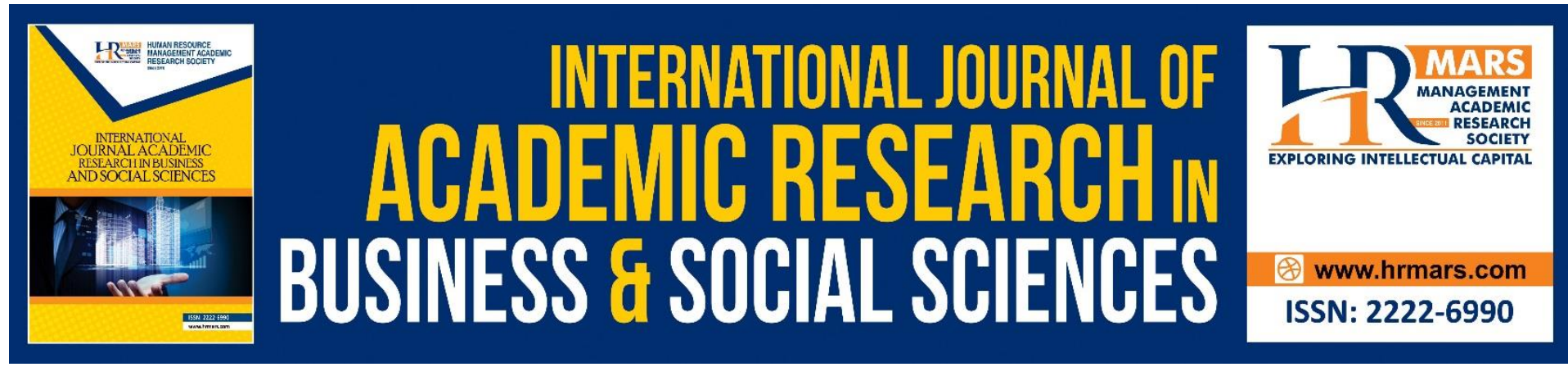

\title{
The Ethical Value of The Youth at Arfiah Shelter Home
}

\author{
Mohd Izhar Ariff Mohd Kashim ${ }^{1}$, Norhafizah Musa², Nurul llyana \\ Muhd Adnan ${ }^{3}$, Siti Suhaila Ihwani ${ }^{4}$, Adibah Muhtar ${ }^{5}$ and Azahar \\ Yaakub $^{6}$ \\ ${ }^{1}$ Research Centre of Sharia, Faculty of Islamic Studies, Universiti Kebangsaan Malaysia, \\ 43600 Bangi, Selangor. Institute of Islam Hadhari, Universiti Kebangsaan Malaysia, 43600, \\ Bangi, Selangor. (Corresponding author), ' Faculty of social sciences and humanities, \\ University of technology Malaysia, ${ }^{3}$ Research Centre for Sharia, Faculty of Islamic Studies, \\ Universiti Kebangsaan Malaysia (UKM), 43600 Bangi, Malaysia, ${ }^{4,5,6}$ Faculty of social sciences \\ and humanities, University of technology Malaysia \\ Email: izhar@ukm.edu.my,norhafizah.kl@utm.my,ilyana_adnan@ukm.edu.my, \\ sitisuhaila@utm.my, adibah_dm@utm.my, azahar.kl@utm.my
}

\begin{abstract}
Promiscuity, incest and rape are the great causes of premarital pregnancy and extramarital births among youth today. This article will study the case of premarital pregnancy among youth at Arfiah Shelter Home, Shah Alam, Selangor. The aim of this article is, first to identify the factors influencing the trainees' involvement. Second, to examines the trainees' perception about the programme conducted. Third, to identify the ethics value after participated in the conducted programme. The study shows most of the youth who are involved in premarital pregnancy are easily influenced by peers and mass media. However after participating in the programme conducted by Arfiah Shelter Home, their ethics shows the improvement become better.
\end{abstract}

Keywords: Youth, Premarital Pregnancy, Illegitimate Child, Ethical Value

\section{Introduction}

Youth involvement in sexual activity at a young age is seen as a big issue. The issue should be taken seriously by the whole society as the sexual activity among youth has begun as early as childhood. This activity would harm the emotion, physical and social development of the children (Kashim et al., 2017).

A journal analysis conducted by Azri et al (2015) which analyzes 30 journal articles between the years 2000 to 2014 found that most journal articles review underage pregnancies because of the rising cases from year to year which seen the states Sabah and Sarawak as the two states in Malaysia with the highest number of premarital pregnancy cases at $62.2 \%$. As of 2013 , there are 510,462 illegitimate children registered with the Social Welfare Department. Based on the findings, this study (Azri et. al., 2015) has identified 6 main factors that cause youth premarital pregnancies which are: 1) Poverty; 2) Practicing sex before 
marriage; 3) No parental monitoring; 4) Low academic achievement; 5) Peer influences and 6) Lack of knowledge about sex, reproduction and health. Most of the articles analyzed by Azri et al (2015) had undertaken surveys towards shelter homes which placed youths with premarital pregnancies. Research suggests that further studies are conducted on youths who have been out of shelter home and living with the community to study what happened to them afterwards.

In Malaysia, premarital pregnancy cases among youths have significant relationship to the increase in cases of baby abandonment (Kashim et al., 2018). Therefore, there is a pressing need to identify factors and causes of youth involvement with premarital pregnancy (Kashim et al., 2017). In addition, programs conducted at the shelter home should be reevaluated to ensure that the trainees that live in the shelter home can change and develop towards being a better person (Kashim et al., 2020a; Kashim et al., 2020c).

\section{Problem Statement}

Various challenges must be faced by parents in raising children in this modern age. There were various social issues that can destroy the civilization of Muslim youth. Most of the highlights in newspapers show about the involvement of youth in premarital pregnancy which seem become terrified and worrying. Statistics from the Ministry of Health in 2015 revealed that a total of 3,980 teenagers aged 10 to 19 were pregnant with premarital children (Utusan, 2016). The scenario of premarital pragnancy among teenagers has been the focus of study conducted by Faizah and Azian (2013). Study by Azriani et al (2011); Faizah \& Azian (2013) found that the main factor of youths to be involved in premarital sexual relationship which cause pregnancy is due to peer influence. A case study had been conducted by Salmi (2013) regarding premarital sex among Malaysian teenagers in which a total of five Malay Muslim students became the respondents of the in-depth study. Findings of the study show that teenagers prefer to discuss about sexuality with friends or boyfriends in comparison to parents, relatives, teachers and counselors.

Youths with premarital pregnancy occupying shelter homes are significant samples in the purpose of studies to understand the growing concern of premarital pregnancies which has significantly increase from year to year (Kashim et al., 2020b). Alavi et al (2012) has conducted a study in a shelter home at Taman Seri Perdana, Cheras housing six respondents aged between 13 and 17 years old. The findings show that most respondents have bad relationship with family and spend more time with friends. Peer influence and information gained from the internet are factors identified to encourage the youth to be involved with premarital sex cases. The respondents also stated that friends were the people they turn to when they are in trouble and were able to help deal with stress that they face at home. This study proposes an important solution to address the problem of youths' premarital pregnancy which is through the constant monitoring from parents and the school. Parents and teachers should cooperate and work together in ensuring that students are not involved with this issue. The study also suggest that every member of the community consisting of parents, adolescents, teachers, communities and ministries to play their respective roles to combat this issue.

Abu Zarin et. al (2017) studied about "Relationship Between Islamic Concept and Ethical Behaviour (Akhlak) of Being In Love Among Youth". Data were collected among students from three types of higher education institution in Malaysia with a total 599 respondents. Findings show that understanding and attitude towards love in Islam is high however the practical aspect is moderate. 


\section{Research Objective}

The objectives of this study are as follows:

1. To identify the factors causing the trainee to be involved in moral misconduct

2. To identify the trainee's perception towards the program implemented at Arfiah Shelter Home

\section{Research Methodology}

The study is a quantitative study utilizing a set of questionnaire being distributed to all trainees residing at the Arfiah shelter home, Shah Alam. The sample of this study consists of 34 trainees who occupy Arfiah shelter home.

\section{Research Findings}

The discussion of the research findings is based on the sections found in the questionnaires that have been answered by the respondents of the study. Part A focuses on the respondent's background, Part $B$ investigates on the factors influencing morality and Part $C$ is the perception of the trainee towards the program that has been implemented.

Respondents' Background

Trainee Age

\section{Table 1.1. The Age Range}

12

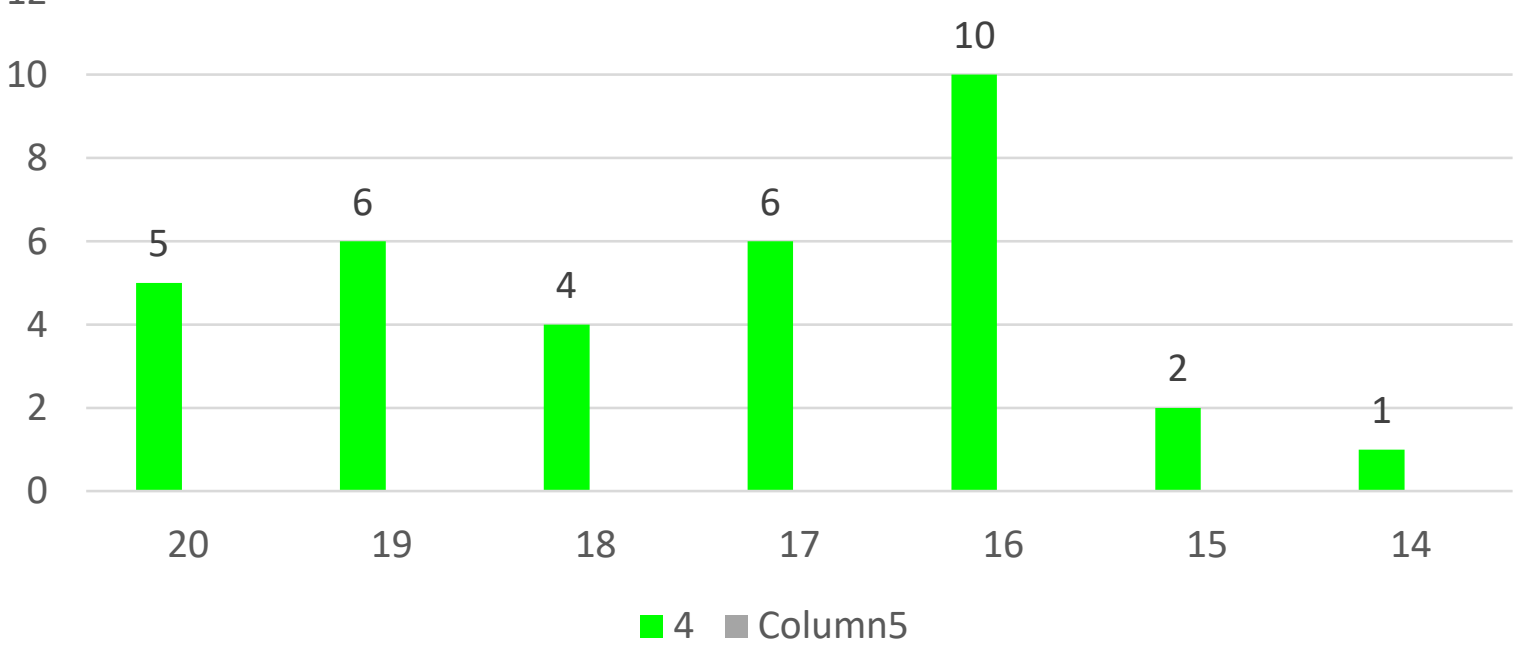

Based on Table 1.1, the age range of the trainee who lives in Arfiah shelter home is between 20 and 14 years old. Research data show that the most number of residents in the Arfiah shelter home is trainees of 16-year-old of age; followed by trainees aged 19 and 17 who have the same number of six trainees. There are five trainees whom are 20-year-old; followed by four trainees aged 18-year-old. A total of two trainees are aged 15 years and the youngest trainee is 14 years old. 


\section{Table 1.2: Parents Marital Status}

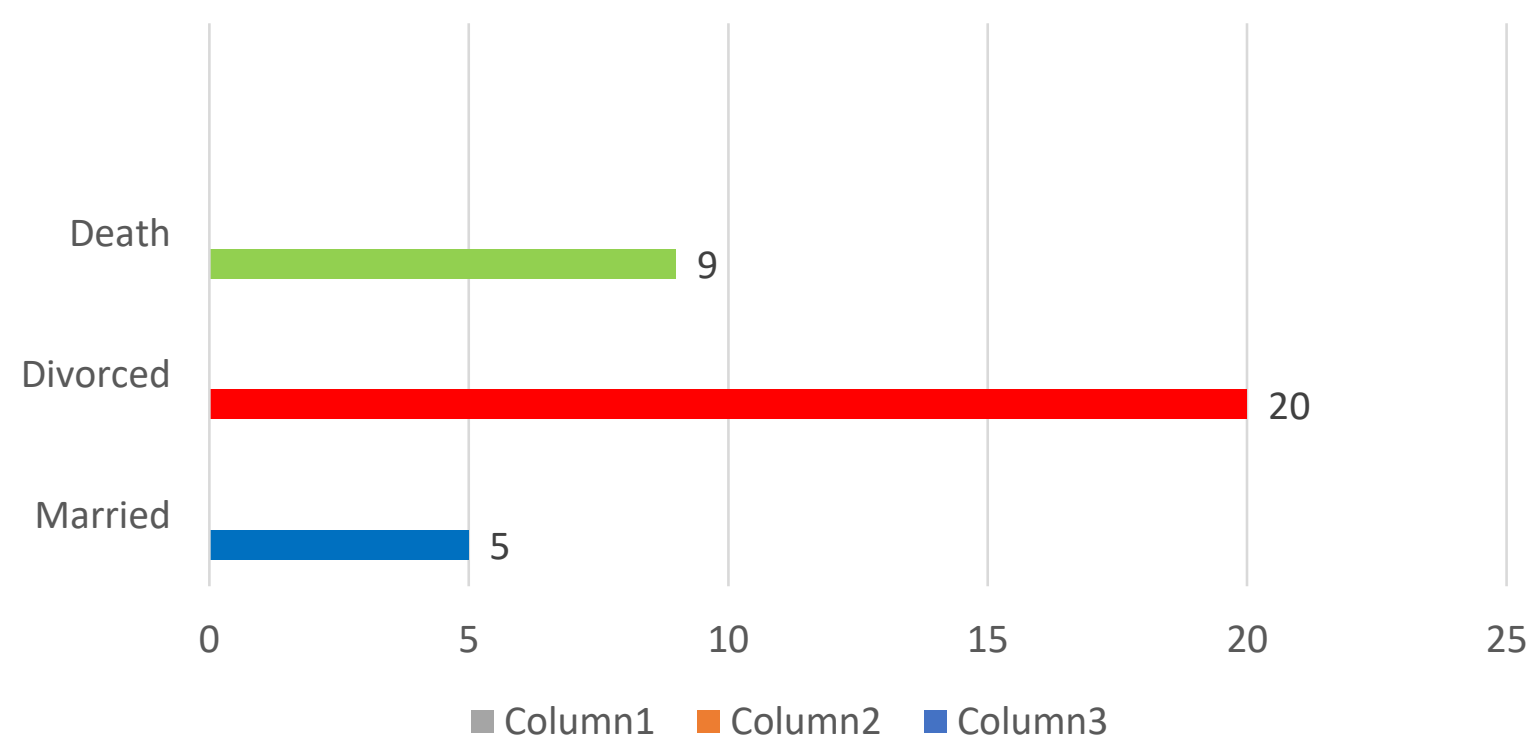

Table 1.2 shows the marital status of the Arfiah shelter home trainee's parents. Most trainees come from divorced families. Based on Table 1.2, 20 trainee stated that their parents were divorced. Meanwhile, nine trainees have lost either their mother or father; and five trainees are still living with their parents.

\section{Involvement in Unethical Activities}

The study shows all trainees living in Arfiah shelter home were involved with immoral activities such as smoking, being disobedient towards parents or guardians, having extreme preference for entertainment, disrespecting teachers, practicing free sex, giving premarital birth and aborting pregnancy and wearing non-syariah compliant dress. All trainees state their involvement in the immoral activities as listed in the questionnaire.

\section{Smoking}

Being disobedient towards parents or guardians

Having extreme preference for entertainment

Disrespecting teachers

Practicing free sex

Giving premarital birth and aborting pregnancy

Wearing non-syariah compliant dress

Part B of the questionnaire aims to identify factors that influence trainees' involvement in the social misconduct. 


\section{Trainees' Involvement Factors}

\section{Chart 1.1: Influences' Factor}

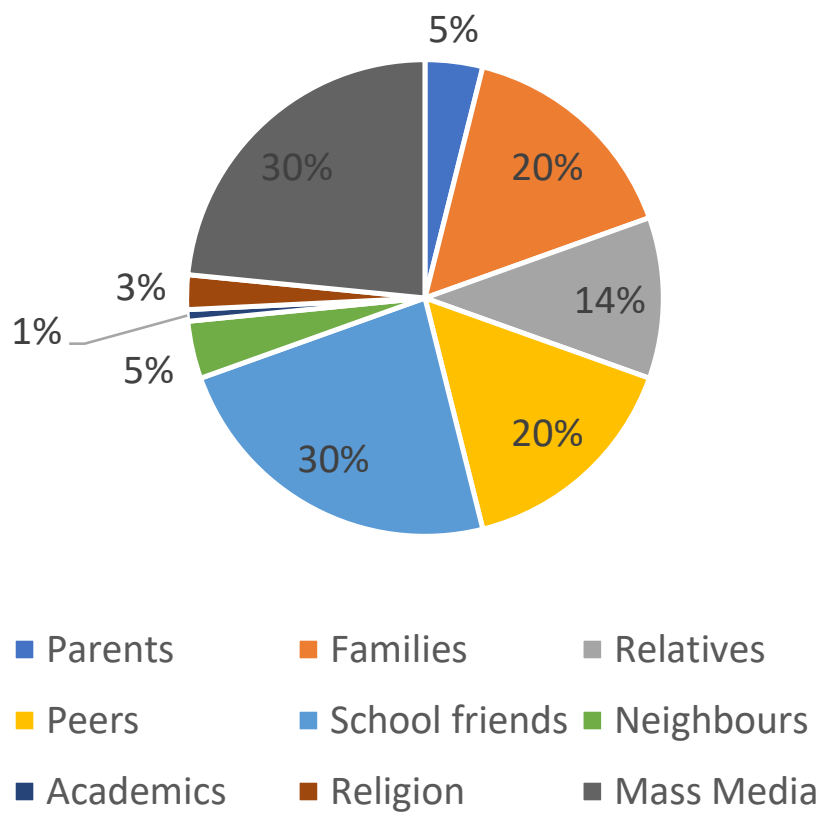

Based on Chart 1.1 above, peers and mass media are reported as the main factors affecting the youths' morality which contributes to $30 \%$. Barbara (2006) stated that youths' behavior stems from the pressure faced due to peer pressure. The influence of peer pressure causes teenagers to have sex due to lack of skills to dismiss friends' requests due to the urge to be accepted by their peers.

Part $C$ aims to examine the perception of the trainee on the program that has been conducted in the Arfiah shelter home. 
Perception of Trainee about the Program Conducted

\begin{tabular}{|l|l|l|l|l|l|l|l|l|}
\hline PP & Program & SD & D & N & A & SA & Mean & S.D. \\
\hline PP1 & $\begin{array}{l}\text { Religious } \\
\text { Class }\end{array}$ & - & - & - & $70 \%$ & $30 \%$ & 3.09 & 1.60 \\
\hline PP2 & $\begin{array}{l}\text { al-Quran } \\
\text { Class }\end{array}$ & - & - & - & $70 \%$ & $30 \%$ & 3.09 & 1.60 \\
\hline PP3 & Hadith Class & - & - & $30 \%$ & $50 \%$ & $20 \%$ & 3.47 & 0.78 \\
\hline PP4 & $\begin{array}{l}\text { Mukmin } \\
\text { Guidance } \\
\text { Class }\end{array}$ & - & - & $30 \%$ & $50 \%$ & $20 \%$ & 3.47 & 0.78 \\
\hline PP5 & $\begin{array}{l}\text { Individual } \\
\text { Counseling }\end{array}$ & - & - & $21 \%$ & $45 \%$ & $34 \%$ & 4.56 & 0.79 \\
\hline PP6 & $\begin{array}{l}\text { Group } \\
\text { Counseling }\end{array}$ & - & - & $30 \%$ & $50 \%$ & $20 \%$ & 3.47 & 0.78 \\
\hline PP7 & $\begin{array}{l}\text { Motivation } \\
\text { Program }\end{array}$ & - & - & $30 \%$ & $50 \%$ & $20 \%$ & 3.47 & 0.78 \\
\hline PP8 & $\begin{array}{l}\text { Self- } \\
\text { development } \\
\text { Program }\end{array}$ & - & - & $21 \%$ & $45 \%$ & $34 \%$ & 4.56 & 0.79 \\
\hline PP9 & Exercise & - & - & $30 \%$ & $50 \%$ & $20 \%$ & 3.47 & 0.78 \\
\hline PP10 & Rest & - & - & $30 \%$ & $50 \%$ & $20 \%$ & 3.47 & 0.78 \\
\hline PP11 & $\begin{array}{l}\text { Out } \\
\text { Games }\end{array}$ & - & - & $21 \%$ & $45 \%$ & $34 \%$ & 4.56 & 0.79 \\
\hline PP12 & Nasyid & - & - & $70 \%$ & - & $30 \%$ & 3.09 & 1.60 \\
\hline PP13 & Zikir & - & - & $70 \%$ & - & $30 \%$ & 3.09 & 1.60 \\
\hline PP14 & $\begin{array}{l}\text { Computer } \\
\text { Class }\end{array}$ & - & - & - & - & $100 \%$ & 5.00 & 1.00 \\
\hline PP15 & $\begin{array}{l}\text { Cooking } \\
\text { Class }\end{array}$ & $1 \%$ & $5 \%$ & $40 \%$ & $30 \%$ & $24 \%$ & 3.59 & 0.59 \\
\hline PP16 & Sewing Class & - & - & - & $20 \%$ & $80 \%$ & 4.56 & 0.79 \\
\hline PP17 & Craft Class & - & $1 \%$ & $19 \%$ & $70 \%$ & $10 \%$ & 4.59 & 0.64 \\
\hline
\end{tabular}

Based on Table 1.3, the frequency distribution analysis by item or statement for the trainee's perception of the program conducted at Arfiah shelter home shows that the 'computer class' program receives the highest mean score (mean $=5.00, s . d=1.00)$. The finding shows that $100 \%$ of the trainees strongly agree that the computer class is the most favorable program among the trainee. Next, the 'individual counseling' and 'outdoor game' programs get the second highest mean score (mean $=4.56, \mathrm{~s} . \mathrm{d}=0.79$ ).

On the other hand, 'nasyid' and 'zikir' programs score the lowest mean (mean $=3.09$, s.d. $=0.59$ ) which shows that $70 \%$ of the trainers agree with the program. This shows that trainees are less interested in nasyid and zikir programs. Overall, the trainee's perception of the programs implemented at the Arfiah shelter home is at good level.

\section{Discussion}

The result shows trainees living at the Arfiah Shelter Home are teenagers between the ages of 14 to 20 years old. The main factor affected teenager ethical value are peers and 
mass media. This result is consistent with the study of Azriani et al (2011); Faizah and Azian (2013) which found that peers is the main factor of teenagers involved in committing premarital sex.

Next, the mass media is also reported as a major factor affecting youths' morality. Study conducted by Alavi et al (2012) is parallel to the findings of this study which show that the factors that encourage teenagers to be involved with the premarital pregnancy are peers and the internet. Most of the applications available on the internet such as WeChat, Facebook, and WhatsApp are among the applications that contribute to social interactions that cause youths to be involved in premarital pregnancy.

\section{Conclusion}

Most teenagers who are pregnant out-of-wedlock are easily influenced by peers and mass media. However, after they participated in the programme conducted by Arfiah Shelter Home, their ethical value shows the improvement become better. Computer classes, individual counseling and outdoor games are programmes that are highly sought after by the trainees and affect the development of the trainee's personality.

\section{Acknowledgment}

We want to express our appreciation to the research project grants, FRGS/1/2019/SSI03/UKM/02/1 provided by Ministry of Higher Education, Malaysia, RH-2020-009 afforded by Institut Islam Hadhari, and UKM for the supports.

\section{References}

Abdul Said, A., Yusof, M. A., Baharom, M., Shukri, Z. dan., Suhaimi, M. T., dan Roslee, T. (2014). Menerapkan kemahiran berfikir. Minda Pendidik di ambil dari http://eprints.ums.edu.my/8398/1/nc0000003879.pdf

Disa, D. F. (2012). Resiliensi pada remaja putri yang mengalami kehamilan tidak diinginkan akibat kekerasan seksual. Jurnal Penelitian dan Pengukuran Psikologi, 1(1), 55-62.

Haslinda, M. (2016). Keberkesanan modul kerohanian pemulihan akhlak remaja di Baitul Ehsan daerah Sabak Bernam, Selangor. Proceedings of the International Conference on Education towards Global Peace, 1-73. url: http://www.iium.edu.my/capeu2016/wp- content/uploads/2017/02/017.pdf

Malia, J. (2014). Peranan Ibu bapa dalam mengatasi masalah remaja. Di ambil 24/11/2017 dari http://bmutkspm.blogspot.my/2014/01/peranan-ibu-bapa-dalam-mengatasi.html

Ghani, F. A., \& Loganathan, T. (2010). Gaya Hidup Remaja Di Sekolah Menengah Kebangsaan Tanjung Peteri Resort, Pasir Gudang, Johor. Universiti Teknologi Malaysia.

Kamal, A. H. (1998). Profil juvana dan pengurusan pemulihan di Asrama Pokok Sena, Kedah. (Unpublished Master Dissertation, Universiti Utara Malaysia).

Kashim, M. I. A .M., Hasim, N. A., Othaman, R., Yahaya, M. Z., Khalid, R., Samsudin, M. A., \& Mat Zin, D. M. (2017). Blood plasma in food from Islam and science perspectives. Sains Malaysiana, 45(12): 1879-1885

Kashim, M. IA. M., Hasim, N. A., Othaman, R., Khalid, R., Samsudin, M. A., Yahaya, M. Z., Abdul Manaf, Z., Amin, L., \& Zin, M. D. M. (2018). Najis (Tinja) manusia daripada perspektif sains dan Islam serta amalan pemakanan sunnah. Sains Malaysiana 47(6): 1227-1234

Kashim, M. I. A. M., Noor, M. A. Y., Abdul Rahman, Z., Radzi, R., Hamjah, S. H., Hasim, N. A., Mohamad, M. N., \& Mokhtar, M. H. (2020a). The rules of sterilization of domestic cats from a Shariah and scientific perspective. Journal of Critical Reviews, 7(6): 1025-1031 
Kashim, M. I. A. M., Ab Rahman, Z., Noor, M. A. Y., Sham, M. F., Hasim, N. A., Safiai, M. H., Mokhtar, M. H., \& Hamjah, S. H. (2020b). Principles regarding the use of haram sources in modern food products: An Islamic perspective. Journal of Critical Reviews, 7(6): 10171024

Kashim, M. I. A. M., Noor, M. A. Y., Ab Rahman, Z., Adnan, M. N. I., Abdul Mutalib, S., Zakaria, M. B., Hasim, N. A., Mokhtar, M. H. (2020c). Animal DNA and halal status of chocolate products in Malaysia. Journal of Critical Reviews 7(6): 1009-1016

Fauziah, M. S., Shah, M. A., Norazani, A., Noor, M. I., \& Che Anuar, C. A. (2015). Aplikasi kaunseling kelompok terhadap konsep kendiri, kemurungan dan daya tahan remaja hamil luar nikah. Jurnal Bitara Edisi Khas (Psikologi Kaunseling), 8, 64-87.

Mahmudi, I. (2016). Peranan bimbingan dan konseling islami dalam menanggulangi kehamilan di luar nikah. Counsellia: Jurnal Bimbingan dan Konseling, 1(1).

Min, J. K. W. (2015). Identifikasi penyesuaian sosial remaja yang menikah akibat hamil di luar nikah di kecamatan Jetis, kabupaten Bantul. Jurnal Bimbingan dan Kaunseling, 4(3), 116.

Norfadilah, A. R., \& Zakaria, S. (2014). Pembangunan kerohanian berasaskan al-Muhasibi dalam menangani gejala sosial masa kini. e-Proceeding of the International Conference on World Conference of Integration Knowledge (WCIK), 69-89. https://worldconferences.net/proceedings/wcik2014/wcik\%20paper

Prisaria, N. (2012). Hubungan Pengetahuan dan Lingkungan Sosial terhadap Tindakan Pencegahan Penyalahgunaan Napza pada Siswa SMA Negeri 1 Jepara (Doctoral dissertation, Fakultas Kedokteran).

Salasiah, H. H., Rosmawati, M. R., Al-Adib, M. S., Fariza, M. S., Zainab, I., \& Zuliza, M. K. (2014). The role of the Muslim family in dealing with adolescent out-of-wedlock pregnancy. Mediterranean Journal of Social Sciences, 5(29), 101-106.

Sarnon, N., Mohamad, M. S., Fauziah, I., Alavi, K., Nen, S., Hoesni, S. M., Zaizul, R., Wan Azreena, J. (2012). Hamil luar nikah: Memahami remaja sebagai asas intervensi keluarga. Journal of Social Sciences and Humanities, 7(1), 121-130.

Stapa, Z., Ismail, A. M., \& Yusuf, N. (2012). Faktor Persekitaran Sosial Dan Hubungannya Dengan Pembentukan Jati Diri (Social Environmental Factors And Their Relation To Identity Formation). Jurnal Hadhari: An International Journal, 155-172.

Susantin, J. (2015). Urgensi kontinuitas pengawasan orang tua terhadap pergaulan anak: studi pada anak hamil di luar nikah. KARIMAN: Jurnal Pendidikan Dan Keislaman, 3(1), 121-132. Retrieved from

http://ejournal.kopertais4.or.id/madura/index.php/kariman/article/view/1800

Utusan Online. (2016). 3,980 remaja hamil anak luar nikah.

Zahrin, S. N. A., Sawai, R. P., Zaini, M. S. F., \& Kasri, A. (2014). Pendekatan Dakwah Melalui 'Konsep Cinta Muslim'dalam Menangani Masalah Sosial. Al-Hikmah, 6(1), 21-34 